\title{
Chemotactic Factor Inactivators of Human
}

\section{Granulocytes}

\author{
John P. Brozna, Robert M. Senior, Donald L. Kreutzer, and \\ Peter A. WARD, Department of Pathology, University of Connecticut \\ Health Center, Farmington, Connecticut 06032, and Departments of \\ Medicine, Washington University School of Medicine and The Jewish \\ Hospital of St. Louis, St. Louis, Missouri 63110
}

A B S T RACT During phagocytosis, neutrophils release a variety of substances that include activators and inactivators of chemotactic factors. It is generally considered that these represent hydrolytic enzymes. Elastase and cathepsin G, major proteases released from lysosomal granules during phagocytosis, contain broad hydrolytic activity. This study examined granule elastase and cathepsin $G$ for their role as inactivators of chemotactic factors. Elastase and cathepsin $\mathrm{G}$ were purified from human neutrophils by Trasylol-Sepharose and CM-cel-

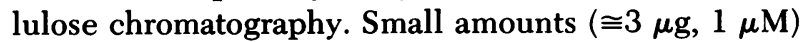
of elastase and cathepsin G, comparable to quantities released by $10^{6}$ neutrophils during phagocytosis, completely inactivated the C5 chemotactic factor generated in human serum. Larger concentrations were needed to inactivate the $\mathrm{C} 3$ chemotactic factor, and when the bacterial chemotactic factor from Escherichia coli was employed, five times more elastase or cathepsin $G$ was ineffective against this chemotactic factor. Supernatant fluid from human neutrophils that had ingested complement-coated zymosan particles contained elastase and cathepsin $\mathrm{G}$ and had inactivator activity for both the $\mathrm{C} 5$ chemotactic fragment and the bacterial factor. A specific inhibitor of elastase largely abolished the inactivator activity in the phagocytic supernates that was directed against C5 factor but did not affect the inactivator activity for the bacterial factor. Similar results occurred in studies of granule lysates. These data indicate heterogeneity in the chemotactic factor inactivator activity released by phagocytosing neutrophils. The predominant inactivator activity of the C5 chemotactic fragment is attributable to elastase and cathepsin G.

Received for publication 15 September 1976 and in revised form 4 August 1977.

\section{INTRODUCTION}

During phagocytosis, polymorphonuclear leukocytes (neutrophils) release factors that both activate and inactivate neutrophil chemotactic factors. The activation occurs primarily through effects on the alternate complement pathway, resulting in generation of chemotactic fragments from $\mathrm{C} 5$, and these chemotactic fragments can also be generated as well as inactivated by direct interaction with a C5-cleaving enzyme released during phagocytosis $(1,2)$.

Two types of substances inhibitory for neutrophil chemotaxis are released from phagocytizing leukocytes. These include a cell-directed inhibitor, termed the neutrophil-immobilizing factor, which directly blocks cellular responses to chemotactic factors, and a second factor which appears to inactivate the C5 chemotactic fragment $(1,3)$. Published data indicate that the neutrophil-immobilizing factor is heat stable, whereas the inactivator activity of the $\mathrm{C} 5$ chemotactic fragment is heat labile at $56^{\circ} \mathrm{C}(1,3)$.

The present study describes further the heat labile chemotactic factor inhibitor activity released by phagocytizing leukocytes. This inhibitory activity affects not only the C5 chemotactic fragment, but also the C3 chemotactic fragment and the bacterial chemotactic factor derived from Escherichia coli. The inactivator activity against the C3 and C5 chemotactic factors is attributable to the neutral proteases, elastase and cathepsin G, which are present in azurophillic granules of polymorphonuclear leukocytes, and is not related to the serum chemotactic factor inactivator $(\mathrm{CFI})^{1}$ previously described (4). The inhibitory activity against

\footnotetext{
${ }^{1}$ Abbreviations used in this paper: CFI, chemotactic factor inactivator; EI, elastase inhibitor; PMN, neutrophilic granulocytes.
} 
the bacterial chemotactic factor, however, is not yet characterized but is different from the proteases listed above.

\section{METHODS}

Materials. Succinyl-L-alanyl-L-alanyl-L-alanine- $p$-nitroanilide was obtained from Bachem (Marina Del Rey, Calif.) and $N$-methyl-2-pyrrolidone was purchased from Eastman Kodak Co. (Rochester, N. Y.). A specific inhibitor of leukocyte elastase, methoxy-Suc-Ala-Pro-Val- $\mathrm{CHCl}_{2}$, was synthesized and kindly supplied by Dr. James C. Powers (Georgia Institute of Technology, Atlanta, Ga.). Benzoyl-L-tyrosine ethyl ester, $\alpha$-chymotrypsin, zymosan, and soybean trypsin inhibitor were purchased from Sigma Chemical Co. (St. Louis, Mo.). Sepharose 4B and dextran are products of Pharmacia Fine Chemicals, Div. of Pharmacia Inc. (Piscataway, N. J.), and carboxymethyl-(CM-) cellulose was from Whatman, Inc. (Clifton, N. J.). Trasylol was a gift from Dr. E. Truscheit, Bayer AG., Wuppertal, West Germany. Ligament elastin was a gift from Dr. Barry C. Starcher (St. Louis, Mo.).

Leukocytes. Leukocytes used for phagocytosis experiments and for subcellular fractionation experiments were obtained from peripheral blood that had been obtained by venipuncture from healthy volunteers. Leukocytes were separated from heparinized blood $(50 \mathrm{U} / \mathrm{ml})$ from several volunteers by dextran sedimentation, washed twice, pooled, and resuspended in Hanks' balanced salt solution. Typically, the differential count in the cell suspension from dextran sedimentation included $76 \%$ neutrophils, $16 \%$ lymphocytes, and $6 \%$ monocytes. In some experiments, the conventional FicollHypaque sedimentation procedure (Ficoll, Pharmacia Fine Chemicals; Hypaque, Winthrop Laboratories, New York) was also employed. The neutrophil-rich zone (pellet), which was used in the studies, consisted of approximately $98 \%$ neutrophils, with minimal contamination by lymphocytes. For the subcellular fractionation procedure, erythrocytes were removed by hypotonic hemolysis in water for $30 \mathrm{~s}$.

Preparation of phagocytic supernatant fluids. Neutrophils, $2 \times 10^{7} / \mathrm{ml}$, were suspended for 5-60 min in Hanks' medium containing zymosan particles $(2 \mathrm{mg} / \mathrm{ml})$. The zymosan particles had been preopsonized by incubation with fresh normal human serum at $37^{\circ} \mathrm{C}$ for $30 \mathrm{~min}(5 \mathrm{mg} \mathrm{zymosan} /$ ml serum). After this, the zymosan particles were washed twice with 25 vol of Hanks' medium. The cells and zymosan particles were then removed by centrifugation. Control supernatant fluids were obtained by incubating $2 \times 10^{7}$ neutrophils in zymosan-free medium. The supernate was used either unconcentrated or after three to fivefold concentration achieved using an Amicon Ultra filtration apparatus with PM-10 membranes (Amicon Corp., Bedford, Mass.).

In companion studies, immune complexes containing bovine serum albumin (BSA) and $20 \mu \mathrm{g}$ nitrogen of rabbit precipitating antibody (present in the IgG fraction) were incubated at $37^{\circ} \mathrm{C}$ for $30 \mathrm{~min}$ with $2 \times 10^{7}$ neutrophils $/ \mathrm{ml}$. These incubations were treated in a manner similar to that previously described when zymosan particles were used. To quantitate the degree of phagocytosis, uptake of radioactivity labeled immune complexes ( ${ }^{125}$ I-BSA) as well as release of $\beta$-glucuronidase were measured (5).

Preparation of leukocyte granule extract. $\cong 3 \times 10^{10}$ leukocytes were obtained from a healthy human volunteer by leukapheresis. The residual erythrocytes were removed by dextran sedimentation, followed by hypotonic hemolysis (see above). The resulting cell suspension from the leukapheresis consisted of $>90 \%$ neutrophils. The leukocytes were pelleted by centrifugation at $800 \mathrm{~g}$ for $10 \mathrm{~min}$. The cell pellet was transferred to a grinding tube (size B, Arthur $\mathbf{H}$. Thomas Co., Philadelphia, Pa.) and homogenized with a drill press in $20 \mathrm{ml}$ isotonic saline, and then centrifuged at $800 \mathrm{~g}$ for $10 \mathrm{~min}$. The supernate was decanted and recentrifuged at $13,000 \mathrm{~g}$ for $20 \mathrm{~min}$. The resultant supernatant fluid, designated cell sap, was removed and stored frozen at $-70^{\circ} \mathrm{C}$. The pellet containing the granules was suspended in $3 \mathrm{ml}$ of phosphate-buffered saline (PBS) and then subjected to seven freeze-thaw cycles using, alternately, dry-ice acetone and tap water. The granule pellet was then centrifuged at $20,000 \mathrm{~g}$ for $30 \mathrm{~min}$ at $4^{\circ} \mathrm{C}$. The clear supernatant fluid was the granule lysate. It was removed and stored in small aliquots at $-70^{\circ} \mathrm{C}$. The remaining pellet containing granule membranes was washed twice by mixing with PBS and centrifugation at $20,000 \mathrm{~g}$ for $30 \mathrm{~min}$. The pellet was then stored at $-70^{\circ} \mathrm{C}$. In some preparations, the granules were disrupted by suspension in $0.2 \mathrm{M}$ sodium acetate, $\mathrm{pH} 4.0$, at $4^{\circ} \mathrm{C}$ overnight, because this procedure achieves improved extraction of cathepsin $\mathrm{G}$ and elastase.

Purification of leukocyte elastase and cathepsin G. Leukocyte elastase and cathepsin $G$ were purified from granule extract by chromatography on Trasylol-Sepharose and CMcellulose, as described by Baugh and Travis (6). The purified enzymes were lyophilized and stored at $4^{\circ} \mathrm{C}$. Enzyme concentrations were determined from their absorbance at 280 $\mathrm{nm}$ and published extinction coefficients. The residual protein in the granule extract, after removal of elastase and cathepsin G, was concentrated with an Amicon ultra filtration cell (PM-10 membrane) to a final volume identical to the volume of granule extract, dialyzed overnight against cold PBS, and stored at $-70^{\circ} \mathrm{C}$.

Enzyme assays. $\beta$-Glucuronidase and acid phosphatase were measured using the substrates phenolphthalein glucuronide and $p$-nitrophenyl phosphate. Elastase activity was measured using succinyl-L-alanyl-L-alanyl-L-alanine- $\boldsymbol{p}$-nitroanilide substrates as previously described with the modification that the reaction volume was kept at $1 \mathrm{ml}$, and that only $10 \mu \mathrm{l}$ of substrate solution was used (7). In some experiments involving either residual granule protein after elastase and cathepsin $G$ removal, or enzyme inhibitors, elastolytic activity was measured with elastin-agar (8). Cathepsin $G$ was determined using benzoyl-L-tyrosine ethyl ester substrate in the modified Hummel assay (9). Lactic dehydrogenase was measured by following the rate of oxidation of NADH according to the method of Wrobleski and LaDue (10). Dilutions were taken into account so that enzyme activity could be related to the amount of enzyme activity present in unfractionated freeze-thawed cell extract. As observed by others, more enzyme activity was recovered when individual subcellular fractions were tested, due apparently to the separation of enzyme inhibitor(s) contained within the cells.

Chemotactic factor inactivator activity. The following were assayed for CFI activity: granule lysates, residual granule lysate after extraction of elastase and cathepsin $G$, purified leukocyte elastase and leukocyte cathepsin $G$, and the residual granule protein after elastase and cathepsin $G$ had been removed by affinity chromatography.

CFI activity was assayed by preincubating the granulocyte components or phagocytic supernates with chemotactic factors. The chemotactic factors included the bacterial chemotactic factor and C3 and C5 chemotactic fragments, generated according to previously established procedures and isolated by molecular sieving techniques (11).

The chemotactic assay involved the modified Boyden chamber and rabbit neutrophils suspended in $0.019 \%$ bovine serum albumin in Hanks' medium containing $0.05 \mathrm{M}$ Tris buffer (pH 7.4) (11). The total number of migrating cells in micro- 
pore filters ( $0.65 \mu \mathrm{m}$ porosity) was assessed by sequential counts at every $10 \mu \mathrm{m}$ depth, all of which were totaled for a given filter (after counting under high power five fields selected at random). Calculation of CFI activity was made on the basis of percent reduction in the chemotactic activity (11).

In experiments involving enzyme inhibitors, the material to be assayed for CFI was preincubated with potential inhibitors for 30 or $60 \mathrm{~min}$ at room temperature or $37^{\circ} \mathrm{C}$. A stock solution of elastase inhibitor (EI) (see above) was prepared by dissolving the substance in methanol at a concentration of $5 \mathrm{mM}$. A fresh $1 \mathrm{mM}$ solution of this inhibitor was made daily by dilution with PBS. The final methanol concentration was $5-10 \%(\mathrm{vol} / \mathrm{vol})$. For control purposes, a dilution of methanol was made in the absence of the inhibitor. When compared with elastase activity in the absence of methanol, no effect of the methanol was found. Soybean trypsin inhibitor was dissolved in PBS at $4 \mathrm{mg} / \mathrm{ml}$ and used in a final concentration of $1-2 \mathrm{mg} / \mathrm{ml}$. The concentration of EI was $100-200 \mu \mathrm{M}$, a range at which the inhibitor was in 20-40fold excess relative to the enzyme concentration. Under these conditions, the EI blocked virtually all elastase activity within $30 \mathrm{~min}$. The EI had no effect upon cathepsin G. Specificity of the inhibitor against elastase in the granule lysate was confirmed by Dr. J. Powers. Soybean trypsin inhibitor (SBTI), as observed by others, completely blocked both elastase and cathepsin $\mathrm{G}(12,13)$.

Subcellular fractionation. Leukocytes isolated from peripheral human blood according to the method of Boyüm were suspended in ice-cold $0.34 \mathrm{M}$ sucrose containing $200 \mathrm{U} /$ $\mathrm{ml}$ of sodium heparin (14). The solution was buffered with $1 \mathrm{mM}$ Tris- $\mathrm{HCl}$ at $\mathrm{pH} 7.0 .1$ vol of buffered sucrose was added for each volume of packed cells. The suspensions were then homogenized at $4^{\circ} \mathrm{C}$ until complete disruption was evident by light microscopy. Fractionation of homogenates into nuclear, granular, microsomal, and cytosal was accomplished by sedimentation in $0.25 \mathrm{M}$ sucrose as described by de Duve (15). Subcellular fractionation was assessed by marker enzyme assays.

CFI activity of granule lysate from which elastase and cathepsin $G$ had been removed. To test for CFI activity in constituents of granule lysate other than elastase and cathepsin G, material eluted from the Trasylol-Sepharose affinity chromatography column that did not contain either elastase or cathepsin $\mathrm{G}$ was incubated with a chemotactic factor for $30 \mathrm{~min}$ at $37^{\circ} \mathrm{C}$.

Blocking by BSA of the CFI activity in granule lysate. Inasmuch as elastase and cathepsin $G$ are proteases with rather broad substrate specificity, an experiment was designed to determine whether high levels of a serum protein (bovine albumin) would block the ability of granule lysates to inactivate the C5 fragment. $5 \mu \mathrm{l}$ of a $25 \%(\mathrm{w} / \mathrm{v})$ solution of BSA was added to $5 \mu \mathrm{l}$ of granule lysate and $40 \mu \mathrm{l}$ of C5 fragment. The mixture was incubated for $30 \mathrm{~min}$ at $37^{\circ} \mathrm{C}$, diluted to $1.0 \mathrm{ml}$ with Hanks' medium, and assayed for residual chemotactic activity. By colorimetric analysis, BSA contained no specific inhibitor activity against the elastase activity in granule lysates, indicating the BSA preparation was free of serum protease inhibitors.

\section{RESULTS}

Release of lysosomal enzymes and chemotactic inactivator activity from phagocytizing leukocytes. Supernatant fluids from suspensions of neutrophils (obtained by dextrose sedimentation) that had ingested opsonized zymosan particles contained elastase,

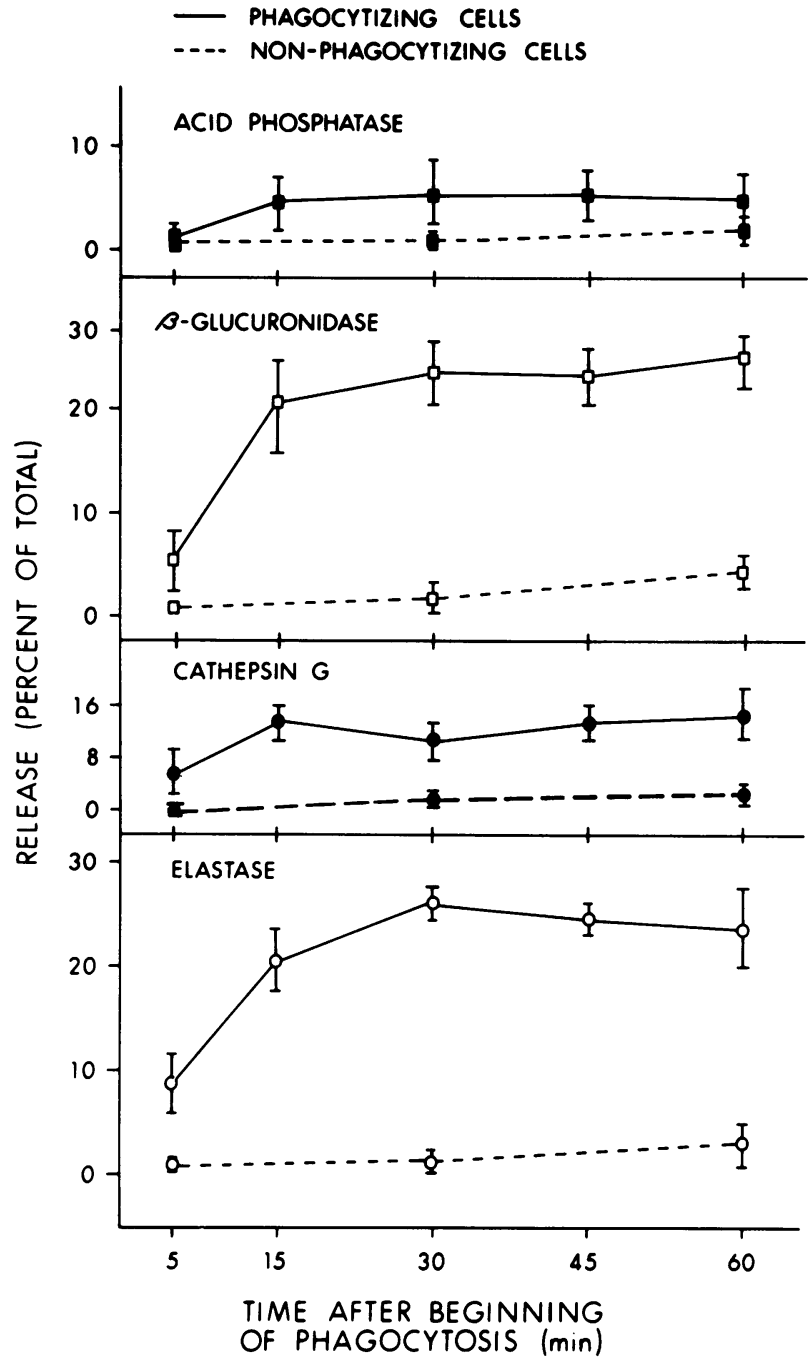

Figure 1 Release of lysosomal enzymes from human leukocytes. Cells were suspended in Hanks' medium in the presence or absence of opsonized zymosan particles. Enzyme activity is expressed as percent of total enzyme measurable in untreated, disrupted cells.

cathepsin G, $\beta$-glucuronidase, acid phosphatase, but little lactic dehydrogenase activity ( $<5 \%$ of total, Fig. 1). These activities were detectable after $5 \mathrm{~min}$ and maximal at $45 \mathrm{~min}$. In addition, inhibitory activity against the bacterial chemotactic factor as well as the C3 and C5 chemotactic fragments was also found, with a plateau of inhibition occurring between 15 and $30 \mathrm{~min}$ (Fig. 2). Chemotactic factor inhibitory activity and lysosomal enzyme activity in supernatant fluids from nonphagocytizing cells were insignificant, with less than $15 \%$ inhibition of the chemotactic activities achieved by these fluids (Fig. 1, 2).

The studies in Figs. 1 and 2 were repeated using the neutrophil-rich zone obtained by Ficoll-Hypaque 


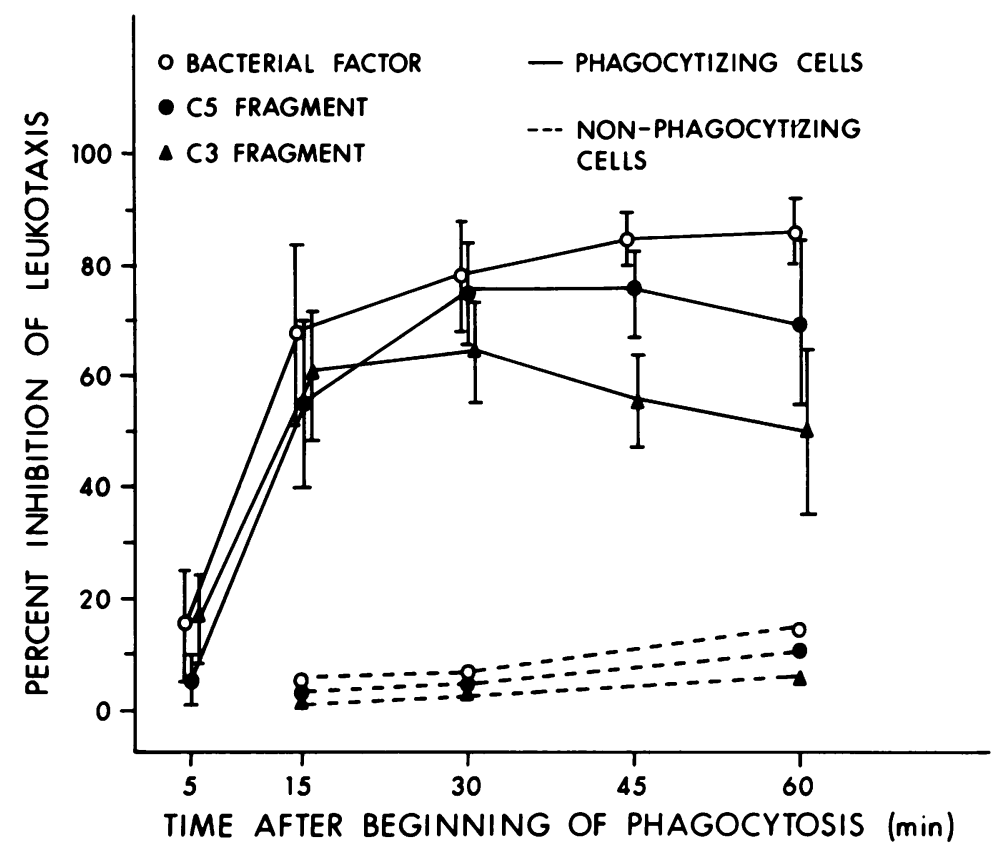

FIGURE 2 Release of chemotactic factor inactivator activity from human leukocytes. $20 \mu \mathrm{l}$ of bacterial chemotactic factor (from $E$. coli) or $50 \mu \mathrm{l}$ of $\mathrm{C} 3$ or $\mathrm{C} 5$ chemotactic fragment was incubated at $37^{\circ} \mathrm{C}$ for $60 \mathrm{~min}$ with supernatant fluids from neutrophils incubated with opsonized zymosan particles and then tested in modified Boyden chambers.

sedimentation (14). Under these conditions, virtually identical data were obtained. For instance, the phagocytic supernatant fluids inactivated each of the three chemotactic factors, and in a time-course which gave virtually superimposable points in Fig. 2. Thus, it appears evident that the CFI under study has derived from neutrophils.

Elastase activity in the phagocytic supernatant fluid at $30 \mathrm{~min}$ corresponded to $10-12 \mu \mathrm{g} / \mathrm{ml}$ of purified elastase, $\cong 20 \%$ of the content of elastase in $2 \times 10^{7}$ cells (Fig. 1) (16). Inasmuch as purified human leukocyte elastase incubated alone in PBS at $37^{\circ} \mathrm{C}$ showed some decline in activity (perhaps due to auto-digestion), the decrease over time in elastase activity in phagocytic supernatant fluids was not unexpected. Acid phosphatase and cathepsin $G$ activities were found in small but significant amounts in the phagocytic cell supernatant fluids (Fig. 1). These data indicate that the chemotactic inactivator activity is released from phagocytizing neutrophils in parallel with lysosomal enzymes.

Similar studies using human leukocytes and immune complexes (in the form of precipitates) as the phagocytic particles indicated that the CFI activity was released during the phagocytosis of immune complexes. When the phagocytic cell supernatant fluids $(100 \mu \mathrm{l})$ from these incubations were assayed for the chemotactic inhibitor, there was $50 \%$ inhibition of the leukotactic response to bacterial chemotactic factor and $40 \%$ inhibition of the response to the C5 chemotactic fragment.

Inhibition of the C5 CFI in phagocytic supernatant fluids. Phagocytic cell supernatant fluids were preincubated with EI or SBTI. Both inhibitors blocked the inactivator activities in phagocytic cell supernatant fluids directed against the C5 chemotactic factor, whereas only SBTI blocked the inactivator of the bacterial chemotactic factor (Table I). Solutions of inhibitors alone or supernatant fluids from non-phagocytizing cells did not show inhibitory chemotactic activity ( $<5 \%$ loss of chemotactic activity) for either of the chemotactic factors tested. These results suggest there are at least two different CFI present in phagocytic supernatant fluid: one that inactivates the C5 chemotactic fragment and another that inactivates the bacterial chemotactic factor.

pH Profile of leukocyte-associate C5 CFI. To determine the $\mathrm{pH}$ optimum for the inactivation of the C5 chemotactic fragment by phagocytic supernatant fluids, $50 \mu \mathrm{l}$ of phagocytic cell supernatant fluids (from neutrophils incubated with opsonized zymosan particles) were incubated with $50 \mu \mathrm{l}$ of C5 fragment and $100 \mu \mathrm{l}$ of $0.4 \mathrm{M}$ Tris-maleate buffer at $37^{\circ} \mathrm{C}$ for $60 \mathrm{~min}$, cooled to $5^{\circ} \mathrm{C}$, and then diluted to $1 \mathrm{ml}$ with Hanks' solution (17). All samples were adjusted to a final $\mathrm{pH}$ of 7.3 for chemotactic assay. In two independent experiments, three distinct zones of inactivator activity were found near $\mathrm{pH}$ values of $5.5,6.8$, and 8.3 (Fig. $3, \mathrm{~A}$ and $\mathrm{B}$ ). 
TABLE I

Effects of Inhibitors upon the CFI Found in Human Leukocyte Phagocytic Supernatant Fluid

\begin{tabular}{|c|c|c|c|c|c|}
\hline \multirow{2}{*}{$\begin{array}{l}\text { Phagocytic } \\
\text { supernate }\end{array}$} & \multirow[b]{2}{*}{ Inhibitor* } & \multirow{2}{*}{$\begin{array}{l}\text { Chemotactic } \\
\text { factor }\end{array}$} & \multicolumn{3}{|c|}{$\begin{array}{l}\text { Inhibition of } \\
\text { chemotaxis } \downarrow \\
\text { Experiment }\end{array}$} \\
\hline & & & $\mathbf{A}$ & B & C \\
\hline$\mu l$ & & & & $\%$ & \\
\hline 50 & None & $B F \S$ & 73 & 87 & 83 \\
\hline 50 & SBTI & BF & 5 & 4 & 29 \\
\hline 50 & EI & BF & 66 & 89 & 83 \\
\hline 50 & None & C5 fragment & 85 & 74 & 72 \\
\hline 50 & SBTI & C5 fragment & 7 & 29 & 21 \\
\hline 50 & EI & C5 fragment & 8 & 25 & 28 \\
\hline
\end{tabular}

* Either SBTI or the EI, Me-O-Suc-Ala-Pro-Val $\mathrm{CHCl}_{2}$, were preincubated for $30 \mathrm{~min}$ at $37^{\circ} \mathrm{C}$ with the phagocytic supernate $(100 \mu \mathrm{l})$.

\$ Phagocytic supernatant fluid $(100 \mu \mathrm{l})$ was incubated at $37^{\circ} \mathrm{C}$ for $60 \mathrm{~min}$ with $20 \mu \mathrm{l}$ of the bacterial chemotactic factor or with $25 \mu \mathrm{l}$ of the C5 fragment. Positive control values for bacterial factor and C5 chemotactic fragment were: $\operatorname{exp~A,~} 250$ and 200; $\operatorname{exp~B,~} 450$ and 450; and exp C, 350 and 600, respectively. Negative values were 20,15 , and 30 , respectively. $\S \mathrm{BF}$, bacterial factor.

Inhibition (by Meo-Suc-Ala-Pro-Val-CHCl ${ }_{2}$ ) of elastase in the phagocytic supernatant fluids removed the CFI activity at $\mathrm{pH} 6.8$ and 8.3 but had no effect on the CFI that was active at $\mathrm{pH}$ 5.5. Elastase has a broad $\mathrm{pH}$ optimum ( $\mathrm{pH} \mathrm{7-8)}$ for its substrate, elastin, but it has little activity at pH 5.5 (18). Taken together these data indicate that the CFI inactivator of C5 fragment at pH 5.5 is not elastase.

Generation of chemotactic activity from whole C5 by phagocytic supernatant fluid or elastase. In one experiment, 50- $\mu$ l samples of purified human C5 (70 $\mu \mathrm{g})$ were incubated at $37^{\circ} \mathrm{C}$ for various intervals of time with either $50 \mu \mathrm{l}$ phagocytic supernatant fluid (from human neutrophils and containing an estimated 1-2 $\mu \mathrm{g}$ elastase) or 1-2 $\mu \mathrm{g}$ purified human leukocytic elastase. At $0,5,15,30,45$, and 60 minutes the incubation mixtures were diluted in ice cold Hanks' solution and then tested for chemotactic activity. Data shown in Fig. 4 indicate that the phagocytic supernatant and purified leukocytic elastase can generate chemotactic activity, and, upon prolonged incubation, the chemotactic activity generated disappears. The ability of phagocytic supernatant fluid to generate chemotactic activity was found to be blocked by the EI. These data, together with those described above, would suggest that the previously described C5 cleaving activity in phagocytic supernates is largely due to elastase released during phagocytosis (2).

Subcellular localization of the chemotactic inhibitor. In two different experiments, leukocytes were fractionated into the nuclear, lysosomal, microsomal, and cytosol fractions, and chemtoactic inhibitory activity of each fraction against the bacterial and C5 chemotactic factors was compared with the inhibitory activity present in crude cell homogenates (Table II). In addition, cell fractions were assayed for lactic dehydrogenase and the lysosomal enzyme markers $\beta$-glucuronidase, acid phosphatase, and elastase.

The lysosomal enzymes were found in large amounts in the granular (lysosomal) fractions and in the cell homogenates; only small amounts were found contaminating the nuclear and microsomal fractions. No elastase activity was detected in the cytosol fraction even by the sensitive elastin-agarose plate method, although small amounts of $\beta$-glucuronidase and phosphatase were present in this fraction. Because of the virtual absence of mitochondria in neutrophils, no attempts were made to isolate this fraction (19).

Chemotactic inhibitory activity was found distributed in all fractions of human neutrophils, but

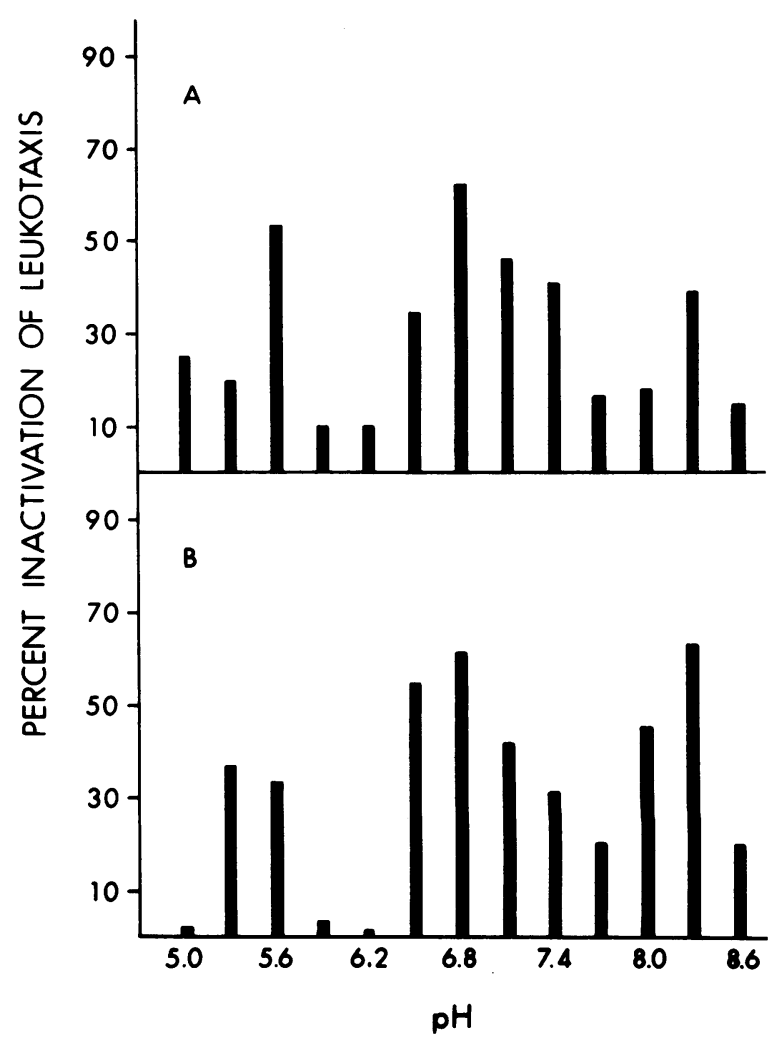

Figure $3 \mathrm{pH}$ profile of the leukocyte C5 chemotactic fragment inactivator. $50 \mu$ l of phagocytic supernatant fluids (details described in Figs. 1 and 2) were incubated with $50 \mu \mathrm{l}$ of $\mathrm{C} 5$ chemotactic fragment and $100 \mu \mathrm{l}$ of Tris-Maleate buffer at $37^{\circ} \mathrm{C}$ for $60 \mathrm{~min}$ at various $\mathrm{pH}$ intervals. The data in the two experiments, $A$ and $B$, represent percent inhibition of leukotaxis. The positive values for experiments $A$ and $B$ were 500 and 350 cells per five high powered fields, respectively. 


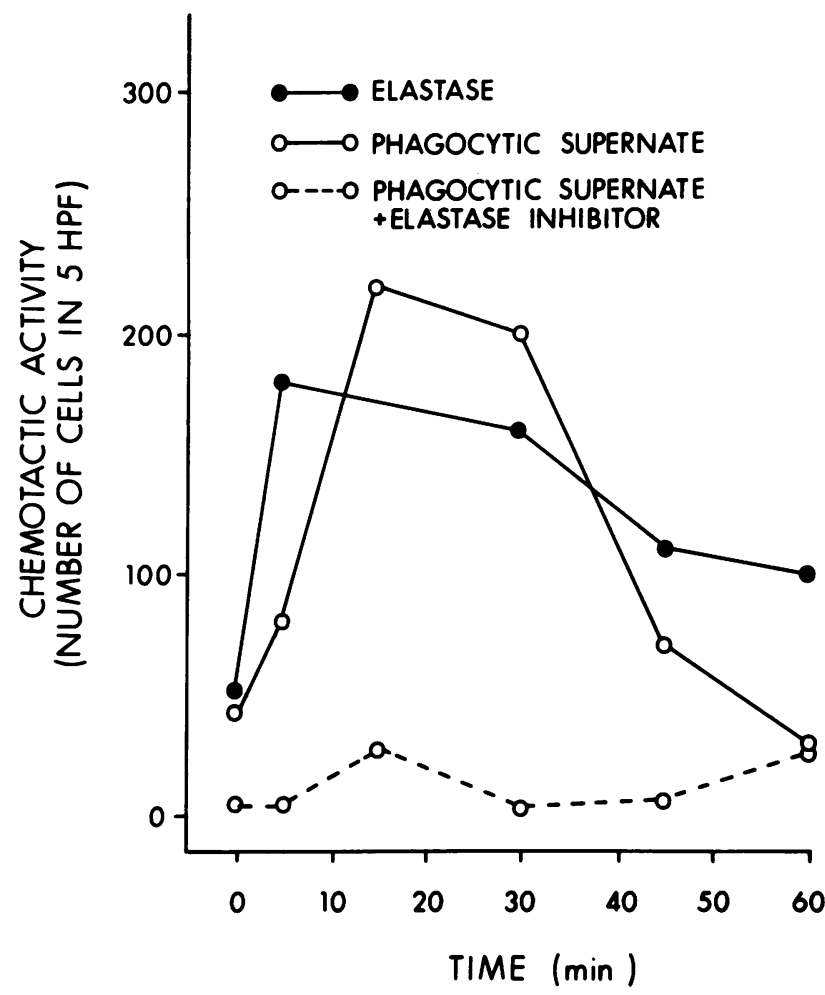

FIGURE 4 Generation of chemotactic activity from whole C5. Phagocytic supernatant fluid (details described in Figs. 1 and 2 ) and purified human leukocyte elastase $(1-2 \mu \mathrm{g})$ were incubated with $50 \mu \mathrm{l}$ of purified C5 $(70 \mu \mathrm{g})$ at $37^{\circ} \mathrm{C}$ for various time intervals. The reaction mixtures were then tested for chemotactic activity in modified Boyden chemotactic chambers. The data represents the number of cells in five high powered fields (HPF). quantitative differences were observed according to the chemotactic factor being used. C5 fragment inactivator was found primarily in the granular fractions whereas bacterial chemotactic factor inactivator activity appeared to be more evenly distributed between the granular and cytosol fractions. The location of elastase activity closely paralleled the location of the inactivator activity of the C5 fragment, a finding consistent with the results (described below) in which the use of EI differentiates inactivator activities for the C5 fragment and the bacterial chemotactic factor.

Effects of lysosomal granule lysate on chemotactic factors. Granule lysates contain CFI activity which is directed against both C5 fragment and bacterial chemotactic factor. Similar to the experiments in which phagocytic supernatant fluids were tested with inhibitors (Table I), prior exposure of the isolated granule lysate to EI or to SBTI blocked virtually all of the CFI activity directed against the C5 chemotactic factor (Table III), whereas the inactivator of the bacterial chemotactic factor was blocked by SBTI but not by EI. Thus, the inactivation of the C5 chemotactic factor either by phagocytic supernatant fluids and (or) by granule extracts from human leukocyte appears to be largely due to the proteolytic action of the lysosomal enzymes elastase and cathepsin G.

Effect of purified human granule elastase and cathepsin $G$ on the leukotactic response to the C3 and C5 fragments and the bacterial chemotactic Factor. Incubating purified elastase $(2.2 \mu \mathrm{g})$ or cathepsin $\mathrm{G}(1.5$ $\mu \mathrm{g})$ with the $\mathrm{C} 5$ chemotactic fragment resulted in abolition of the chemotactic activity (Fig. 5). In contrast, experiments using as much as $17 \mu \mathrm{g}$ of either enzyme

TABLE II

Subcellular Location of Chemotactic Factor Inactivators of Human Leukocytes

\begin{tabular}{|c|c|c|c|c|c|c|c|c|c|c|c|c|}
\hline \multirow[b]{2}{*}{ Subcellular fraction ${ }^{*}$} & \multicolumn{4}{|c|}{ Chemotactic factor inhibitor } & & & \multirow{2}{*}{\multicolumn{2}{|c|}{$\begin{array}{c}\beta \text {-Glucuroni- } \\
\text { dase }\end{array}$}} & \multirow{2}{*}{\multicolumn{2}{|c|}{$\begin{array}{c}\text { Acid } \\
\text { phosphatase }\end{array}$}} & \multirow{2}{*}{\multicolumn{2}{|c|}{$\begin{array}{l}\text { Lactic de- } \\
\text { hydrogenase }\end{array}$}} \\
\hline & & & & & Elastase & & & & & & & \\
\hline & & & & & \multicolumn{8}{|c|}{ \% of total enzyme } \\
\hline $\begin{array}{l}\text { Experiment } \\
\text { Leukocyte }\end{array}$ & $\mathbf{A}$ & B & $\mathbf{A}$ & B & $\mathbf{A}$ & B & $\mathbf{A}$ & B & $\mathbf{A}$ & B & $\mathbf{A}$ & B \\
\hline homogenate & 74 & 50 & 70 & 55 & 100 & 100 & 100 & 100 & 100 & 100 & 100 & 100 \\
\hline Nuclear & 19 & 25 & 27 & 20 & 12 & 20 & 8 & 20 & 14 & 22 & 15 & 28 \\
\hline Granular & 78 & 42 & 65 & 50 & 99 & 56 & 88 & 70 & 50 & 47 & 5 & 10 \\
\hline Microsomal & 30 & 10 & 19 & 0 & 11 & 3 & 4 & 9 & 6 & 12 & 0 & 0 \\
\hline Cytosol & 55 & 52 & 24 & 20 & 2 & 2 & 20 & 6 & 24 & 10 & 78 & 60 \\
\hline
\end{tabular}

* Each subcellular fraction ( $25 \mu \mathrm{l})$ was incubated with the bacterial chemotactic factor $(20 \mu \mathrm{l})$ or with $\mathrm{C} 5 \mathrm{chemotactic}$ factor $(50 \mu \mathrm{l})$ for $60 \mathrm{~min}$.

\$ The number of cells migrating in five high powered fields in response to bacterial chemotactic factor and to C5 chemotactic factor in exp A was 550 and 450, and in exp B was 600 and 600, respectively. The negative control in both experiments was $<20$. 
TABLE III

Effects of Inhibitors upon the C5 Fragment-Directed CFI Present in Granule Lysates

\begin{tabular}{|c|c|c|c|c|c|}
\hline \multirow{2}{*}{$\begin{array}{c}\text { Granule } \\
\text { lysate }\end{array}$} & \multirow[b]{2}{*}{ Inhibitor* } & \multirow{2}{*}{$\begin{array}{l}\text { Chemotactic } \\
\text { factor }\end{array}$} & \multicolumn{3}{|c|}{$\begin{array}{l}\text { Inhibition of } \\
\text { chemotactic } \\
\text { activity } \\
\text { Experiment }\end{array}$} \\
\hline & & & $\mathbf{A}$ & B & $\mathrm{C}$ \\
\hline$\mu l$ & & & & $\%$ & \\
\hline 5 & none & C5 fragment & 89 & 96 & 85 \\
\hline 5 & SBTI & C5 fragment & 0 & 40 & 0 \\
\hline 5 & EI & C5 fragment & 2 & 12 & 0 \\
\hline
\end{tabular}

* Experiment performed in identical manner as described in Table I.

\$ Net positive values for C5 fragment for $\exp A, B$, and C were 325,256 , and 200 , respectively.

did not affect the chemotactic activity of the bacterial factor. Elastase and cathepsin $G$ were able to inactivate $\mathrm{C} 3$ chemotactic factor, but at 10 times the concentration of enzyme required for $\mathrm{C} 5$ fragment inactivation. These data indicate that purified elastase and cathepsin $\mathrm{G}$ can inactivate the C5 chemotactic factor, and to a lesser extent, the C3 chemotactic factor,

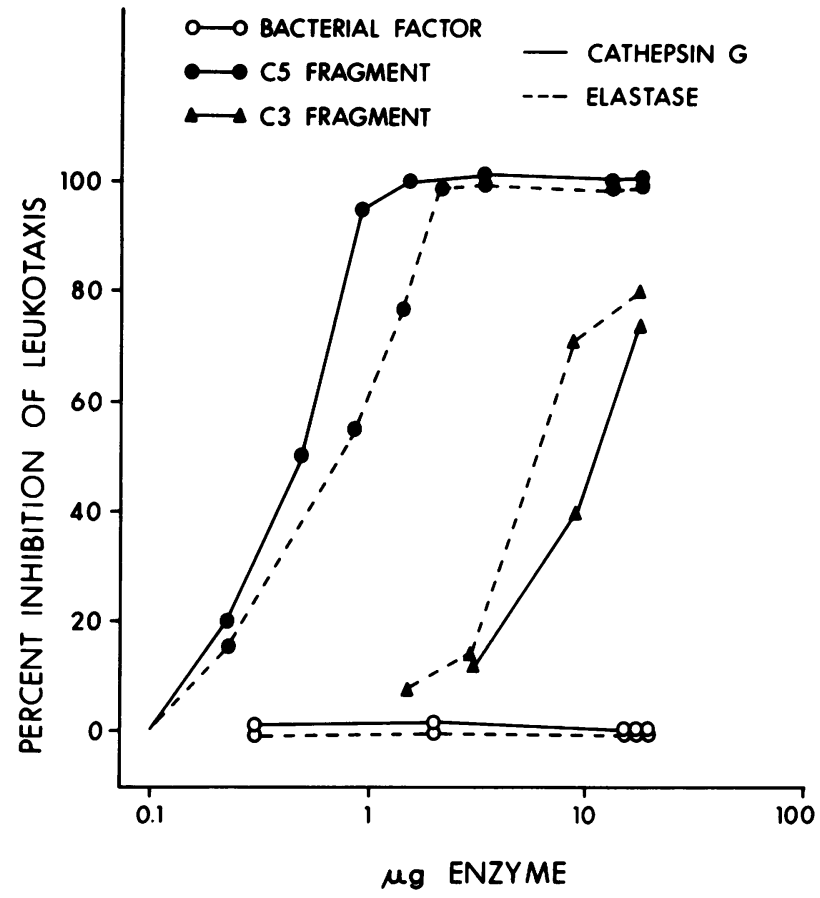

Figure 5 Inactivation of the C3, C5, and bacterial, chemotactic factors. Varying amounts of purified human leukocyte elastase and cathepsin G were incubated with $50 \mu$ l of C3 or C5 chemotactic fragment or $20 \mu$ l of bacterial chemotactic factor. The data represents percent inhibition of leukotaxis by either elastase or cathepsin G. The positive values for the C3, C5, and bacterial chemotactic fragment were 200, 240, and 300 , respectively. whereas the bacterial chemotactic factor is resistant to inactivation by these enzymes.

CFI activity of granule lysate after removal of elastase and cathepsin G. Eluates of the TrasylolSepharose column that did not contain either elastase or cathepsin G had no CFI activity against C5 fragment. The result was still negative even with eluate from ten times as much of the starting granule lysate as was needed to completely inactivate the C5 fragment. In contrast, the eluate displayed some (50-75\%) CFI activity against bacterial factor.

Interaction of inactivator in phagocytic cell fluids with chemotactic factor. To determine whether the chemotactic inhibitor in phagocytic cell supernatant fluids was acting on the chemotactic factors or was directed against the leukocytes, supernatant fluids from leukocytes (obtained after $40 \mathrm{~min}$ of phagocytosis) were mixed with either the bacterial chemotactic factor (present in the lower compartment of the chemotactic chamber) or with the cell suspension (present in the upper compartment of each chamber). These results indicated that $80-92 \%$ of the chemotactic response was inhibited by the phagocytic supernatant fluid after mixture with the chemotactic factor, whereas addition of the phagocytic fluid to the cell suspension resulted in only 10-29\% inhibition of the chemotactic response. A second experiment (Table IV) revealed evidence for the direct interaction of the inhibitor with the chemotactic factor. Supernatant fluids (100 $\mu \mathrm{l})$ from human leukocytes, which had phagocytized zymosan particles, or leukocyte granule lysate $(5 \mu \mathrm{l})$ were heated at $56^{\circ} \mathrm{C}$ for $1 \mathrm{~h}$, either before or after incubation with the $\mathrm{C} 5$ chemotactic factor $(10 \mu \mathrm{l})$ or the bacterial chemotactic factor $(100 \mu \mathrm{l})$. The C5 chemotactic factor and the bacterial factor, mixed with buffer, were found (as expected) to be heat stable. If the mixtures of cell supernatant fluid or granule lysate and chemotactic factor were heat-inactivated after the inhibitor had been allowed to interact with the chemotactic factor, the percent inactivation was similar to that in unheated controls. However, if the phagocytic supernatant was heated at $56^{\circ} \mathrm{C}$ for $1 \mathrm{~h}$ before the addition of chemotactic factor, the inhibitory activity dropped from 76 and $88 \%$ to 27 and $29 \%$ for the C5 chemotactic factor whereas the granule lysate inhibition of the C5 chemotactic factor dropped from 100 to $52 \%$ after heat treatment (Table IV). Likewise, preheating the supernatant fluid removed its ability to inactivate the bacterial chemotactic factor.

Nondialyzable nature of the chemotactic factor inhibition. Supernatant fluids from human leukocytes phagocytizing zymosan particles for $30 \mathrm{~min}$ were dialyzed for $24 \mathrm{~h}$ against PBS, pH 7.1, and then tested for inhibitory activity against bacterial and the $\mathrm{C} 3$ and C5 chemotactic factors. Inhibitory activity was not lost after dialysis of the supernatant fluids for $24 \mathrm{~h}$. Thus, the chemotactic inhibitor present in phagocytic 
TABLE IV

Heat Lability of CFI from Human Leukocytes

Heat treatment of supernatant fluid*

\begin{tabular}{ccc}
\hline None & $\begin{array}{c}\text { Before } \\
\text { incubation }\end{array}$ & $\begin{array}{c}\text { After } \\
\text { incubation }\end{array}$ \\
\hline
\end{tabular}

Inactivation of chemotactic activity

$\%$

With C5 chemotactic factor

Granule lysate $(5 \mu \mathrm{l})$

99

$52 \quad 100$

$(100 \mu \mathrm{l})$

$20 \mathrm{~min}$

$40 \mathrm{~min}$

Buffer

Phagocytic cell supernate

$(100 \mu \mathrm{l})$

Buffer

$40 \mathrm{~min}$

\begin{tabular}{|c|c|c|}
\hline- & 27 & 76 \\
\hline 90 & 29 & 88 \\
\hline \multirow[t]{2}{*}{2} & - & 6 \\
\hline & \multicolumn{2}{|c|}{$\begin{array}{c}\text { With bacterial } \\
\text { chemotactic factor }\end{array}$} \\
\hline & 4 & 77 \\
\hline & - & 2 \\
\hline
\end{tabular}

* Treatment consisted of $56^{\circ} \mathrm{C}$ for 60 min either before or after incubation with the chemotactic factor. $50 \mu \mathrm{l}$ of C5 fragment or $20 \mu \mathrm{l}$ of bacterial chemotactic factor was used, with each giving chemotactic counts of 205 and 185, respectively. The blank control gave a chemotactic count of 5 .

supernatant fluids is nondialyzable and acts directly and irreversibly on the chemotactic factors. On a functional basis, the inhibitor can be classified as a CFI.

Effect of BSA on granule lysate CFI activity of granule lysates. Incubation of granule lysates with BSA completely blocked the CFI activity of granule lysates directed against C5 fragment. Full chemotactic activity was found in the mixture of BSA, granule lysate, and C5 fragment: counts of 205 vs. 200 for the C5 fragment alone, and 215 for the C5 fragment plus BSA. In contrast a mixture of granule lysate and C5 fragment, in amounts and under identical conditions, resulted in total inactivation of the chemotactic activity of the C5 fragment. These data indicate that BSA can block the ability of granule lysate to inactivate the C5 fragment probably by serving as an alternate substrate. This is not surprising in view of the fact that elastase and cathepsin $\mathrm{G}$ can hydrolyze diverse proteins and peptides.

\section{DISCUSSION}

These results indicate that the principal neutral proteases in granules of neutrophils (PMN), namely elastase and cathepsin G, have the capacity to inactivate chemotactic factors derived from $\mathrm{C} 3$ and $\mathrm{C} 5$. The findings are not surprising because the C3 and C5 chemotactic factors are believed to be peptides of appreciable size $(10,000$ daltons or more), and the PMN neutral proteases have broad proteolytic activity. Indeed, Venge and Olson (20) have already shown inactivation of the chemotactic activity of $\mathrm{C} 5$ by cathepsin G, and Johnson et al. (21) have speculated that PMN elastase and collagenase may inactivate chemotactic factors once these same enzymes have generated chemotactic fragments from native C3 and C5. What is notable in this study, however, is the observation that neutral proteases sufficient to inactivate complement-derived chemotactic factors are released from small numbers of phagocytizing PMN. It would appear that neutral proteases account for the C5 CFI released from PMN described by Wright and Gallin (1).

The potential for regulation of leukotaxis by PMN neutral proteases is suggested by these data. However, one might suspect that these proteases have only a minor role, in that they can be readily inhibited by circulating and by tissue-related inhibitors such as $\alpha$-1-antitrypsin, $\alpha$-2-macroglobulin, and the inhibitor present in bronchial secretions of humans (22). It is to be stressed that the presence of these inhibitors renders difficult any appraisal of the role in inflammatory reactions of PMN neutral proteases, not only in regulating leukotaxis, but also in bacterial killing and digestion and in the pathogenesis of pulmonary emphysema and inflammatory joint disease in which a role for PMN proteases has been incriminated (23).

It was of interest to find that PMN-associated CFI activity for the bacterial factor was distinguishable from the PMN-associated CFI activity effective against complement-derived chemotactic factors. The bacterial factor used in these studies was a crude mixture that probably contains lipid as well as peptides. Had a partially purified preparation been used, such as the previously described pronase-sensitive factor, the preparation might have been found susceptible to the PMN neutral proteases (24). In any event, the PMN appears to have multiple types of CFI activity, and the data indicate a structual difference between bacterial chemotactic factor and complement chemotactic factors.

PMN neutral proteases are distinct from the CFI activity in serum. Serum CFI is not affected by $\alpha$-1antitrypsin, $\alpha$-2-macroglobulin, SBTI, or chloromethylketones, all of which block the neutral proteases. The molecular weight of serum CFI appears to be much larger than the molecular weights of the neutral proteases. $^{2}$

From a functional standpoint, serum CFI and the PMN neutral proteases also show marked differences. Minute amounts of serum CFI can inactivate C3and C5-derived chemotactic factors even in mixtures containing other proteins in high concentrations. This

${ }^{2}$ Kreutzer, D. L., W. D. Claypool, M. L. Jones, and P. A. Ward. Purification and characterization of serum chemotactic factor in activator. Manuscript submitted for publication. 
reflects great specificity of the serum CFI for these chemotactic factors. On the other hand, PMN neutral proteases do not display such specificity, inasmuch as their effectiveness as CFI diminishes markedly at low concentrations (less than about $1 \mu \mathrm{M}$ ) or in the presence of albumin, which apparently can serve as a substrate. Thus, it would appear that the PMN neutral proteases appear to have CFI activity only as a by-product of their broad hydrolytic activity.

The experiments employing granule lysates and purified elastase and cathepsin G support the conclusion that the CFI activity is released by phagocytosing PMN. Use of PMN granule lysates is complicated, however, by the methods chosen for PMN collection, granule recovery, and extraction. We collected large numbers of PMN by leukapheresis, a technique that may alter the cells (25). Moreover, the conditions for preparation of granule lysates favor recovery of easily soluble material that is active at neutral $\mathrm{pH}$. It is possible that different methods of preparation and extraction would have yielded different relative amounts of the proteases and even other proteases. For example, collagenase, present in azurophillic granules, and capable of cleaving $\mathrm{C} 3$, was not studied $(21,26)$. It may be concluded that the granule extract we studied does not entirely reflect granules within circulating PMN.

The data from this study indicate that the concept of CFI has to be expanded to include PMN neutral proteases. Although lacking in the great specificity seen with serum CFI, these substances may still play a part in regulation of the inflammatory response.

\section{ACKNOWLEDGMENTS}

This study was supported in part by grants AI 13940, AI 09651, HL 07202, and HL 16118 from the National Institutes of Health.

\section{REFERENCES}

1. Wright, D. G., and J. I. Gallin. 1975. Modulation of the inflammatory response by products released from human polymorphonuclear leukocytes during phagocytosis: generation and inactivation of the chemotactic factor C5a. Inflammation. 1: 23-40.

2. Ward, P. A., and J. H. Hill. 1970. C5 chemotactic fragments produced by an enzyme in lysosomal granules of neutrophils. J. Immunol. 104: 535-543.

3. Goetzl, E., and K. F. Austen. 1972. A neutrophil-immobilizing factor derived from human leukocytes. I. Generation and partial characterization. J. Exp. Med. 136: $1564-1580$.

4. Berenberg, J. L., and P. A. Ward. 1973. The chemotactic factor inactivator in normal human serum. J. Clin. Invest. 52: 1200-1206.

5. Ward, P. A., and N. J. Zvaifler. 1973. Quantitative phagocytosis by neutrophils. I. A new method with immune complexes. J. Immunol. 111: 1771-1775.

6. Baugh, R. J., and J. Travis. 1976. Human leukocyte granule elastase: rapid isolation and characterization. Biochemistry. 15: 836-841.
7. Levine, E. A., R. M. Senior, and J. Butler. 1976. The elastase activity of alveolar macrophages: measurements using synthetic substrates and elastin. Am. Rev. Respir. Dis. 113: 25-30.

8. Werb, Z., and S. Gordon. 1975. Elastase secretion by stimulated macrophages. Characterization and regulation. J. Exp. Med. 142: 361-377.

9. Kang, S. H., and M. J. Fuchs. 1973. An improvement in the Hummel chymotrypsin assay. Anal. Biochem. 54: 262-265.

10. Wroblewski, F., and J. C. LaDue. 1955. Lactic dehydrogenase activity in blood. Proc. Soc. Exp. Biol. Med. 90: $210-215$.

11. Ward, P. A., R. Data, and G. Till. 1974. Regulatory control of complement derived chemotactic and anaphylatoxin mediators. In Progress in Immunology II. L. Brest and J. Holborow, editors. North-Holland Publishing Co. I: 209-215.

12. Starkey, P. M., and A. J. Barrett. 1976. Human lysosomal elastase: catalytic and immunological properties. Biochem. J. 155: 265-271.

13. Starkey, P. M., and A. J. Barrett. 1976. Human cathepsin G: catalytic and immunological properties. Biochem. J. 155: 273-278.

14. Boyüm, A. 1968. Isolation of mononuclear cells and granulocytes from human blood. Scand. J. Clin. Lab. Invest. 21 (Suppl. 97): 77-89.

15. de Duve, C. 1971. Tissue fractionation, past and present. J. Cell. Biol. 50: 20d-55d.

16. Taylor, J. C., and J. P. Crawford. 1975. Purification and characterization of human leukocyte elastase. Arch. Biochem. Biophys. 169: 91 (Abstr.)

17. Brozna, J. P., and P. A. Ward. 1975. Antileukotactic properties of tumor cells. J. Clin. Invest. 56: 616-623.

18. Ohlsson, K., and I. Olsson. 1974. The neutral proteases of human granulocyte. Isolations and partial characterization of granulocyte elastase. Eur. J. Biochem. 42: 579.

19. Schwind, J. L. 1950. The supravital method in the study of the cytology of blood and marrow cells. Blood. 5: 597-622.

20. Venge, P., and I. Olsson. 1975. Cationic proteins of human granulocytes VI. Effects on the complement system and mediation of chemotactic activity. J. Immunol. 115: 1505-1508.

21. Johnson, U., K. Ohlsson, and I. Olsson. 1976. Effects of neutral proteases on complement components. Scand.J. Immunol. 5: 421-426.

22. Ohlsson, K., and H. Tegner. 1976. Inhibition of elastase from granulocytes by the low molecular weight bronchial protease inhibitor. Scand. J. Clin. Lab. Invest. 36: $437-445$.

23. Janoff, A. J. Blondin, R. A. Sandhaus, A. Mosser, and C. J. Mallmud. 1975. Human neutrophil elastase: In vitro effects on natural substrates suggest important physiological and pathological actions. Cold Spring Harbor Conf. Cell Proliferation. 2: 603-620.

24. Schiffmann, E., H. V. Showell, B. A. Corcoran, P. A. Ward, E. Smith, and E. L. Becker. 1975. The isolation and partial characterization of neutrophil chemotactic factors from Escherichia coli.J. Immunol. 114: 1831-1837.

25. Wright, D. G., J. C. Kauffmann, M. J. Chusid, G. P. Herzig, and J. I. Gallin. 1975. Functional abnormalities of human neutrophils collected by continuous flow filtration leukopheresis. Blood. 46: 901-911.

26. Ohlsson, K., I. Olsson, and J. K. Spitznagel. 1977. Localization of chymotrypsin-like cationic protein, collagenase and elastase in azurophil granules of human neutrophilic polymorphonuclear leukocytes. Hoppe-Seyler's Z. Physiol. Chem. 358: 361-366. 